\title{
BEST PRACTICE IMPLEMENTASI SUPERVISI AKADEMIK UNTUK MENINGKATAN PROFESIONAL GURU DI MTs KECAMATAN KAJORAN MELALUI BIMBINGAN DAN LATIHAN
}

\author{
SYAIFUL FAIZIN \\ Pengawas Sekolah Madya pada Kementerian Agama Kabupaten Magelang, Jawa Tengah, \\ Wilayah Kecamatan Kajoran \\ Email : syaifulfaizin@gmail.com
}

\begin{abstract}
ABSTRAK
Guru profesional adalah SDM yang memiliki kompetensi pedagogik, kompetensi kepribadian, kompetensi sosial, dan kompetensi profesional. Guru profesional merupakan SDM unggul berkompeten pada aspek : (1) memiliki keahlian mendidik dalam bidangnya, (2) memiliki rasa tanggung jawab yang berkomitmen dan peduli terhadap tugasnya, dan (3) memiliki rasa kesejawatan, menghayati tugasnya sebagai guru serta mampu menjaga kode etik profesinya. Fakta di lapangan, banyak guru yang belum berkompeten dalam bidangnya, belum memiliki tanggung jawab, komitemen dan kepedulian terhadap peserta didik serta belum memiliki rasa kesejawatan, penghayatan terhadap profesi dan mampu menjaga kode etik profesinya. Oleh karena itu perlu dilakukan supervisi akademik melalui metode bimbingan dan latihan profesional guru. Tujuan penyusunan best practice untuk menentukan langkah-langkah implementasi supervisi akademik untuk peningkatan sumber daya manusia di MTs Kecamatan Kajoran Melalui Bimlat. Pelaksanaan supervisi akademik melalui Bimlat adalah (1) penyusunan administrasi pembelajaran lengkap dari $49 \%$, menjadi $83 \%$ guru telah melengkapi administrasi pembelajaran; (2) pemanfataan teknologi informasi dan komunikasi dari $32 \%$ menjadi $73 \%$; (3) pemanfaatan media pembelajaran dari $33 \%$ menjadi $79 \%$; (4) penggunaan model pembelajaran kontekstual dari $34 \%$ menjadi $80 \%$; (5) pemanfaatan internet pada proses pembelajaran dari $30 \%$ menjadi $78 \%$; (6) ketepatan menaati jadwal pembelajaran dari $61 \%$ menjadi $93 \%$ serta (7) kesadaran melakukan inovasi pembelajaran dari $49 \%$ menjadi $83 \%$. Implementasi supervisi akademik melalui bimbingan dan latihan profesional guru dapat meningkatkan profesional guru pada aspek yang menjadi permasalahan di MTs Se Kecamatan Kajoran.
\end{abstract}

Kata Kunci : Best Practice, Akademik, Peningkatan Profesional Guru

\section{PENDAHULUAN}

Guru adalah sumber daya manusia di sekolah/madrasah, sebagai ujung tombak peningkatan kualitas pendidikan di sekolah/madrasah. Salah satu program peningkatan profesional guru dalam manajamen SDM dengan mengimplementasikan beberapa aspek, antara lain melalui implementasi fungsi manajerial dan fungsi operasional dalam manajemen sumber daya manusia. Fungsi manajerial mencakup perencanaan, pengorganisasian, pelaksanaan dan pengawasan. Sedangkan fungsi operasional meliputi pengadaan, fungsi pengembangan, fungsi kompensasi, fungsi intergrasi dan fungsi pemeliharaan (Wukir, 2013: 52). Implementasi fungsifungsi tersebut harus melihat kondisi yang ada di sekolah/madrasah, karena bagi sekolah/madrasah swasta masalah pengadaan menjadi tumpuan utama kinerja sekolah/madrasah. Hal ini disebabkan sistem sekolah/madrasah swasta pengadaan SDM merupakan kewenangan sekolah/madrasah. Aspek lain perlu memperhatikan fungsi pengembangan, fungsi kompensasi, fungsi intergrasi dan fungsi pemeliharaan. Fungsi-fungsi tersebut lebih fokus penekanan pada peningkatan SDM guru karena guru adalah agent of change di sekolah/madrasah.

Guru adalah jabatan profesi, karena untuk menjadi guru yang profesional, seseorang harus menempuh pendidikan profesi. Seperti yang tercantum pada UU No.14 Tahun 2005 tentang guru dan dosen pasal 1 butir 1 disebutkan bahwa "Guru adalah pendidik profesional dengan tugas utama mendidik, mengajar, membimbing, mengarahkan, melatih, menilai, dan 
mengevaluasi peserta didik pada pendidikan anak usia dini jalur pendidikan formal, pendidikan dasar, dan pendidikan menengah" Guru profesional memiliki empat kompetensi, yakni kompetensi pedagogik, kompetensi kepribadian, kompetensi sosial, dan kompetensi profesional yang diperoleh melalui pendidikan profesi (UU RI No. 14 Tahun 2005 pasal 10 butir 1). Guru profesional merupakan sumber daya manusia yang unggul, seharusnya memiliki ciri-ciri : (1) memiliki keahlian mendidik dalam bidangnya, (2) memiliki rasa tanggung jawab yang berkomitmen dan peduli terhadap tugasnya, dan (3) memiliki rasa kesejawatan, menghayati tugasnya sebagai guru serta mampu menjaga kode etik profesinya (Sahertian, 2010: 2).

Untuk memperoleh derajat Guru profesional harus dipersiapkan dengan matang. Salah satu peningkatan profesional guru sesuai dengan tugas pokok dan fungsi pengawas adalah mengimplementasikan fungsi pengawasan (supervisi). Supervisi menurut Suhardan (2010) adalah pengawasan terhadap kegiatan akademik berupa persiapan pembelajaran, pelaksanaan pembelajaran, tindak lanjut pembelajaran, pengawasan terhadap siswa yang belajar dan pengawasan terhadap situasi yang menyebabkannya. Pengawasan dalam pendidikan merupakan pelayanan terhadap kebutuhan pokok guru agar mampu meningkatkan potensinya sehingga benar-benar menjadi sumber daya manusia di sekolah/madrasah yang profesional secara berkesinambungan. Pelaksanaan kegiatan supervisi di sekolah/madrasah, salah satunya menjadi tanggung jawab kepala sekolah/madrasah sebagai supervisor. Dalam hal ini pengawas mendampingi proses supervisi.

Fenomena yang terjadi di Madrasah Tsanawiyah Swasta Kecamatan Kajoran Kabupaten Magelang bahwa aktivitas guru dan kepala sekolah/madrasah dalam melaksanakan tugas pokok dan fungsinya adalah : 1) sebagian besar guru masih menerapkan pembelajaran yang konvesional dengan metode ceramah, tanya jawab, pemberian tugas; 2) minat dan motivasi guru dalam inovasi yang masih rendah, hal ini ditunjukkan dengan adanya sikap guru yang cenderung apatis dengan adanya berbagai pembaharuan, dan merasa nyaman dengan kondisi rutinitas; 3) dalam melaksanakan pembelajaran guru kurang memanfaatkan media, sehingga pembelajaran cenderung membawa siswa hanya untuk membayangkan apa yang dipelajari (pembelajaran kurang nyata/riil); 4) guru tidak melengkapi administrasi akademik (RPP dibuat dengan meniru milik orang lain tanpa penyesuaian yang signifikan, adminisrasi penilaian dan jurnal pembelajaran belum terdokumentasi dengan baik; 5) guru sering meninggalkan kelas saat jam mengajar dan hadir tidak tepat waktu pada jam mengajar, 6) supervisi Kepala Sekolah/Madrasah dilaksanakan satu kali dalam satu semester dengan tujuan hanya untuk kepentingan administrasi PKG, tanpa disertai tindak lanjut.

Berdasar informasi sementara dari kepala madrasah, guru dan siswa, permasalahan tersebut disebabkan adanya beberapa hal yang menghambat, antara lain: 1) pengawasan (supervisi) terhadap kinerja guru dari atasan yang masih kurang karena masih terbatas pada kepentingan administratif PKG dan TPG; 2) masih banyak guru yang kurang mendukung terhadap kegiatan berinovasi; 3) fasilitas multi media yang belum tersedia secara merata di semua kelas. Hambatan-hambatan tersebut perlu untuk segera diselesaikan, jika tidak segera diatasi akan berpengaruh pada kinerja guru dan dampak selanjutnya dapat berpengaruh pada rendahnya kualitas lulusan/siswa sebagai muara dari kegiatan pendidikan.

Berdasar hal tersebut dapat dikategorikan kinerja guru sebagai sumber daya manusia utama dalam pendidikan di Madrasah Tsanawiyah binaan masih rendah. Padahal tuntutan yang ada guru adalah agent of change, dan menjadi seorang yang benar-benar profesional dalam bidangnya demi terwujudnya pendidikan yang berkualitas. Salah satu upaya memperbaiki kondisi tersebut, kepala madrasah didampingi oleh pengawas pembina selaku manajer SDM telah melakukan kegiatan yang mampu mewujudkan tercapainya sumber daya manusia yang bermutu melalui kegiatan supervisi dengan bimbingan dan latihan.

Tujuan penulisan best practice ini diharapkan dapat menentukan langkah-langkah implementasi supervisi akademik untuk peningkatan sumber daya manusia di MTs Kecamatan Kajoran Melalui Bimbingan dan Latihan. 
1. Secara teoritis dapat memberikan wawasan dan pengetahuan tentang implementasi supervisi akademik untuk meningkatkan sumber saya manusia di MTs Kecamatan Kajoran melalui Bimlat, bagi Kepala Madrasah, Guru dan Pengawas Pembina.

2. Secara praktis diharapkan dapat dijadikan bahan rujukan bagi pengelola (stake holder) madrasah dalam rangka meningkatkan mutu madrasah pada implementasi supervisi akademik melalui Bimlat.

Dalam suatu organisasi sekolah/madrasah yang menjadi sumber daya manusia utama (kunci) adalah guru dan kepala madrasah yang dibantu oleh tenaga administrasi (tenaga kependidikan). Pengembangan sumber daya manusia dalam organisasi suatu madrasah merupakan usaha untuk memperbaiki kapasitas kemampuan guru/tenaga pendidik dan tenaga kependidikan agar lebih produktif. Pengelolaan sumber daya manusia merupakan hal penting dalam organisasi madrasah karena madrasah yang bermutu tergantung dengan sumber daya manusia sebagai agent of change di madrasah.

Tujuan pengelolaan tenaga pendidik dan tenaga kependidikan (guru dan pegawai Tata Usaha) menurut Aas Syaefudin (2005: 103) dalam dalam Herawan \& Hartini (2012: 232) adalah supaya mereka mempunyai kemampuan, motivasi dan kreativitas untuk: 1) mewujudkan sistem sekolah/madrasah yang mampu mengatasi kelemahannya sendiri; 2) secara berkesinambungan menyesuaikan program pendidikan sekolah/madrasah terhadap tututan dan kebutuhan peserta didik dalam menghadapi persaingan secara sehat dan dinamis; 3) menyediakan kader pemimpin pendidikan yang handal dan dapat menjadi teladan.

Menurut UU No. 14 Tahun 2005 pasal 20, guru harus melaksanakan tugas sebagai berikut a) merencanakan pembelajaran, melaksanakan proses pembelajaran yang bermutu, serta menilai dan mengevaluasi hasil pembelajaran; b) meningkatkan dan mengembangkan kualifikasi akademik dan kompetensi secara berkelanjutan sejalan dengan perkembangan ilmu pengetahuan, teknologi, dan seni; c) bertindak objektif dan tidak diskriminatif atas dasar pertimbangan jenis kelamin, agama, suku, ras, dan kondisi fisik tertentu, atau latar belakang keluarga, dan status sosial ekonomi peserta didik dalam pembelajaran; d) menjunjung tinggi peraturan perundang-undangan, hukum, dan kode etik guru, serta nilai-nilai agama dan etika; dan e) memelihara dan memupuk persatuan dan kesatuan bangsa.

Menurut Surya, M.H. (2004: 38-41), tantangan abad 21 guru sebagai sumber daya manusia di sekolah/madrasah hendaknya memiliki sembilan profil, yaitu: 1) memiliki semangat juang yang tinggi; 2) mampu mengikuti perkembangan jaman dan iptek; 3) mampu belajar dan bekerja sama dengan profesi lain; 4) memiliki etos kerja yang tinggi; 5) memiliki kejelasan dan kepastian pengembangan jenjang karier; 6) berjiwa profesionalisme yang tinggi; 7) memiliki kesejahteraan lahir dan batin (materian \& non-material); 8) memiliki visi ke depan; dan 9) mampu melaksanakan fungsi dan perananya secara terpadu.

Salah satu fungsi manajemen sumber daya manusia adalah fungsi pengawasan (supervisi), maka supervisi ini menjadi hal yang penting dalam menjaga mutu SDM. Menurut Purwanto (2014: 89) supervisi terbagi menjadi dua yaitu supervisi umum dan supervisi pendidikan, supervisi umum berkaitan dengan supervisi yang dilakukan pada pekerjaanpekerjaan secara umum di luar kependidikan (pengajaran), seperti administrasi kantor, keuangan, kepegawaian, proyek dan sebagainya. Sedangkan supervisi yang berkaitan dengan pendidikan dinamakan supervisi akademik, yaitu serangkaian kegiatan membantu guru mengembangkan kemampuannya mengelola proses belajar mengajar demi pencapaian tujuan pembelajaran (Daresh, 1989, Glickman, et al. 2007 dalam Kemendikbud, 2012:15). Pengertian tersebut merujuk pada usaha membantu guru dalam menjalankan tugasnya sebagai sosok pembelajar. Hal ini senada dengan yang disampaikan oleh Masaong, H.A. Kadim (2012: 3) supervisi mengandung beberapa aspek, yaitu: 1) bersifat bantuan dan pelayanan kepada kepala sekolah/madrasah, guru dan staf; 2) mengembangkan kualitas guru; 3) pengembangan profesionalan guru; dan 4) usaha memotivasi guru. Sutarsih \& Nurdin (2012: 313), juga mendukung pendapat tersebut, bahwa supervisi akademik adalah bimbingan profesional bagi 
guru-guru sehingga lebih mampu melaksankan tupoksinya dalam rangka memperbaiki dan menyempurnakan proses pembelajaran.

Dari uraian tersebut, dapat disimpulkan bahwa supervisi akademik adalah kegiatan pengawasan terhadap kegiatan pembelajaran yang dilaksanakan guru dalam rangka meningkatkan mutu pembelajaran, sehingga proses belajar mengajar dapat menghasilkan mutu lulusan yang lebih baik.

Prinsip-prinsip supervisi akademik yang ditulis oleh Sahertian (2010: 20) adalah: 1) prinsip ilmiah (scientefic), yaitu kegiatan supervisi dilaksanakan berdasar data obyektif yang diperoleh pada pelaksanaan proses belajar mengajar melalui wawancara (alat perekam), angket, observasi dan pelaksanaanya secara sistematis, berencana serta kontinu; 2) prinsip demokratis, yaitu menjujung tinggi harga diri dan martabat guru, bukan berdasarkan hubungan atasan bawahan, tapi berdasarkan rasa kesejawatan; 3) prinsip kerjasama, yaitu mengembangkan usaha bersama atau menurut istilah "supervisi sharing of idea, sharing of experience" memberi support, dorongan, menstimulus guru, sehingga mereka merasa tumbuh bersama; dan 4) prinsip konstruktif dan kreatif, yaitu supervisi yang mampu mencipatakan suasana kerja yang menyenangkan sehingga guru-guru termotivasi untuk mengembangkan potensi keratifitasnya.

Menurut Swearingen (1961) dengan bukunya yang berjudul Supervision of Instrumen Foundation and Dimension dalam Sahaertian $(2010: 21)$ terdapat delapan fungsi supervisi yaitu : 1) mengoordinasi semua usaha sekolah/madrasah;2) memperlengkapi kepememimpinan sekolah/madrasah; 3) memperluas pengalaman guru-guru; 4) menstimulasi usaha-usaha yang kreatif; 5) memberi fasilitas dan penilaian yang terus-menerus; 6) menganalisis situasi belajar mengajar; 7) memberikan pengetahuan dan ketrampilan pekada setiap anggota staf; dan 8) memberi wawasan yang lebig luas dan terintegrasi dalam merumuskan.

Pendekatan supervisi dalam Sahartian (2010: 46-52) ada 3 bentuk, yaitu:

1. Pendekatan direktif

2. Pendekatan direktif yaitu suatu cara pendekatan terhadap masalah yang bersifat langsung dengan memberikan arahan secara langsung. Supervisor melaksanakan supervisi dengan beberapa cara anatara lain : menjelaskan, menyajikan, mengarahkan, memberi contoh, menetapkan tolok ukur dan memberi penguatan serta mengarahkan tindak lanjut;

3. Pendekatan non-direktif

4. Pendekatan non-direktif, yaitu cara pendekatan terhadap masalah yang bersifat tidak langsung. Supervisor tidak langsung menunjukkan permasalahan, tetapi secara aktif mengidentifikasi permasalahan yang dikeluhkan oleh guru pada proses pembelajaran. Dalam pendekatan ini kegiatan supervisor dimulai dengan : mendengarkan, mengidentifikasi masalah, memberi penguatan, menjelaskan, menyajikan dan menyelesaikan masalah.

5. Pendekatan kolaboratif

6. Pendekatan kolaboratif, yaitu suatu cara pendekatan yang memadukan penekatan direktif dengan non-direktif menjadi cara pendekatan baru, sehingga guru bersama dengan supervisor bersepakat untuk menetapkan struktur, proses, dan kriteria dalam melaksanakan proses penyelesaian masalah yang dihadapi guru. Dalam pendekatan ini supervisi berhubungan pada dua arah, yaitu dari atas dan bawah, maka adapun kegiatan supervisor dimulai dengan: menyajikan, menjelaskan, mendengarkan, menyelesaikan masalah dan negosiasi.

Prosedur supervisi akademik adalah rangkaian program kegiatan supervisi, menurut Kemendikbud (2015: 17-18) prosedur supervisi akademik terdiri atas :

1. Tahap persiapan, meliputi menyiapkan instrumen dan menyiapkan jadwal bersama;

2. Tahap pelaksanaan, yaitu pelaksanaan observasi supervisi baik secara langsung maupun tidak langsung; 
3. Tahap pelaporan, meliputi mengidentifikasi hasil pengamatan pada saat observasi, menganalisa hasil supervisi, mengevaluasi bersama, kemudian membaut catatan hasil supervisi sebagai dokumen untuk pelaporan;

4. Tahap tindak lanjut, meliputi: berdiskusi dan membuat solusi bersama, menyampaikan hasil pelaksanaan supervisi akademik dan mengkomunikasikan hasil supervisi akademik kepada kepala sekolah/madrasah dan guru.

Pelaksanaan supervisi akademik melalui bimbingan dan latihan bagi guru binaan. Pengertian bimbingan menurut Crow \& Crow (Prayitno, 2004: 94) adalah bantuan yang diberikan oleh seseorang, yang memiliki kepribadian yang memadai dan terlatih dengan baik kepada individu-individu setiap usia untuk membantunya mengatur kegiatan hidupnya sendiri, mengembangkan pandangan hidupnya sendiri, membuat keputusan sendiri, dan menanggung bebannya sendiri. Menurut Crow \& Crow tersebut layanan bimbingan yang diberikan pada individu atau sekumpulan individu berguna untuk menghindari dan mengatasi masalah dalam kehidupannya secara mandiri.

Donald G. Mortenson dalam (Marsudi, 2003: 31) berpendapat bahwa bimbingan adalah: a. bimbingan merupakan bagian dari program pendidikan $b$. bimbingan merupakan bantuan dan kesempatan setiap orang c. bimbingan diberikan oleh petugas yang memiliki keahlian d. bimbingan individu diharapkan dapat berkembang sesuai dengan kemampuannya e. dasar bimbingan ialah demokrasi. Secara prinsip pendapat Donald G. Mortenson menyatakan bahwa bimbingan merupakan pemberian bantuan kepada setiap orang yang dilakukan oleh ahli dalam bidang bimbingan, dan diharapkan dengan bimbingan tersebut orang yang diberikan bimbingan dapat berkembang sesuai dengan kemampuannya.

Pendapat Bimo Walgito (2004: 5) bahwa bimbingan adalah bantuan atau pertolongan yang diberikan kepada individu atau sekumpulan individu dalam menghindari atau mengatasi kesulitan-kesulitan di dalam kehidupannya, agar individu atau sekumpulan individu itu dapat mencapai kesejahteraan hidupnya. Berdasarkan pengertian tersebut dapat disimpulkan bahwa bimbingan adalah salah satu bentuk proses pemberian bantuan kepada individu atau sekumpulan individu dalam memecahkan masalahnya, sehingga masing- masing individu akan mampu untuk mengoptimalkan potensi dan keterampilan dalam mengatasi setiap permasalahan, serta mencapai penyesuaian diri dalam kehidupannya.

Bimbingan merupakan "proses bantuan terhadap individu agar ia memahami dirinya dan dunianya, sehingga dengan demikian ia dapat memanfaatkan potensi-potensinya".

Goldstsein dan Gressner (1988) dalam Kamil (2010, hlm. 6) mendefinisikan pelatihan sebagai usaha sistematis untuk menguasai keterampilan, peraturan, konsep, ataupun cara berperilaku yang berdampak pada peningkatan kinerja. Selanjutnya menurut Dearden (1984) dalam Kamil (2010, hlm.7) yang menyatakan bahwa pelatihan pada dasarnya meliputi proses belajar mengajar dan latihan bertujuan untuk mencapai tingkatan kompetensi tertentu atau efisiensi kerja. Sebagai hasil pelatihan, peserta diharapkan mampu merespon dengan tepat dan sesuai situasi tertentu Seringkali pelatihan dimaksudkan untuk memperbaiki kinerja yang lngsung berhubungan dengan situasinya.

Selanjutnya Fiedman dan Yarbrough dalam Sudjana (2007, hlm.4) menunjukan bahwa pelatihan adalah upaya pembelajaran, yang diselenggarakan oleh organisasi (instansi pemerintah, lembaga swadaya masyarakat, perusahaan, dan lain sebagainya) untuk memenuhi kebutuhan atau untuk mencapai tujuan organisasi. Lebih jauh Sastrodipoera (2006) dalam Kamil (2010, hlm.152) memberikan definisi pelatihan adalah "salah satu jenis proses pembelajaran untuk memperoleh dan meningkatkan keterampilan diluar sistem pengembangan sumber daya manusia, yang berlaku dalam waktu yang relatif singkat dengan metode yang lebih mengutamakan taktik daripada teori”. Sejalan dengan pendapat diatas Sastraadipoera (2006, hlm.121) menyebutkan juga bahwa pelatihan bisa dianggap sebagai suatu proses penyampaian pengetahuan, keterampilan, dan pembinaan sikap dan kepribadian.

Secara opersional dapat dirumuskan secara sederhana bahwa bimbingan dan latihan profesional guru adalah pelaksanaan gagasan, perencanaan, pelaksanaan dan tindak lanjut 
melalui proses bantuan terhadap guru sebagai tenaga profesi yang menerapkan standar mutu terhadap pelaksanaan pekerjaan profesi pada jenjang pendidikan dasar dan menengah pada jalur pendidikan formal agar ia memahami tugas pokok dan fungsinya dalam melaksanakan tugasnya sebagai guru profesional.

\section{METODE PENELITIAN}

Penelitian ini ada penelitian tindakan pengawasan terhadap guru binaan yang bersifat deskriptif, menggambarkan supervisi akademik melalui kegiatan bimbingan dan latihan profesional bagi guru binaan agar dapat meningkatkan profesional guru pada proses pembelajaran. Langkah-langkah dalam melaksanakan bimbingan dan latihan bagi Guru MTs Swasta binaan untuk meningkatkan kompetensi profesional guru pada proses pembelajaran menurut pendapat Oemar Hamalik (2004: 199) yang diadaptasi sesuai permasalahan kegiatan ini adalah sebagai berikut :

1. Langkah 1 : menentukan indikator-indikator kesenjangan permasalahan rendahnya kualitas profesional Guru MTs Swasta binaan berdasarkan hasil Supervisi Akademik Kepala Madrasah bersama Pengawas;

2. Langkah 2 : melakukan analisis penyebab terjadinya kesenjangan masalah yang dihadapi oleh Guru, selanjutnya menetapkan faktor utama yang diduga paling dominan terhadap masalah profesional guru yakni : (1) penyusunan administrasi pembelajaran lengkap; (2) administrasi pembelajaran berbasis ITC; (3) proses pembelajaran berbasis media; (4) pelaksanaan model pembelajaran CTL; (5) pemanfaatan internet pada pembelajaran; (6) ketepatan jadwal pembelajaran dan (7) kesadaran inovasi pembelajaran

3. Langkah 3 : menetapkan metode yang akan digunakan untuk melakukan peningkatan profesional guru yaitu bimbingan dan latihan untuk meningkatkan kompetensi profesional Guru Madrasah binaan pada 7 (tujuh) aspek tersebut di atas;

4. Langkah 4 : melakukan bimbingan dan latihan pada 7 (tujuh) aspek kepada Guru Madrasah binaan secara berkelompok sesuai jadwal;

5. Langkah 5 : menugaskan kepada Guru Madrasah binaan berusaha memecahakan masalah yang dialaminya secara berkelompok terhadap 7 (tujuh) aspek tersebut;

6. Langkah 6 : pendampingan pelaksanaan kegiatan pembelajaran pada 7 (tujuh) aspek kempetensi profesional Guru Madrasah binaan oleh Kepala Madrasah dan Pengawas;

7. Langkah 7 : pelaksanan evaluasi dan tindak lanjut kegiatan terhadap 7 (tujuh) aspek kompetensi profesional Guru Madrasah binaan oleh Kepala Madrasah dan Pengawas.

Berdasarkan paparan pendapat di atas, dapat disimpulkan bahwa langkah-langkah dalam pelaksanaan bimbingan dan latihan bagi Guru Madrasah binaan adalah identifikasi indikator permasalahan, melakukan analisis terhadap permasalahan, menentukan metode penyelesaian masalah, melaksanakan bimbingan dan latihan; penugasan untuk kemandirian penyelesaian masalah, pendampingan pelaksanaan pembelajaran dan evaluasi serta tindak lanjut kegiatan pembelajaran pada 7 (tujuh) aspek kompetensi profesional Guru Madrasah binaan.

Bila supervisi akademik terhadap kompetensi profesional Guru Madrasah binaan telah dilaksanakan dengan baik oleh Kepala Madrasah bersama Pengawas dilanjutkan dengan bimbingan dan latihan profesional guru untuk mengatasi kesenjangan terhadap kompetensi profesional guru binaan, maka kompetensi profesional Guru Madrasah binaan dalam 7 (tujuh) aspek akan mengalami peningkatan yang signifikan.

\section{HASIL DAN PEMBAHASAN}

Kondisi sebelum dilakukan supervisi akademik yang sesuai standar adalah sebagai berikut: 
1. sebagian besar guru masih menerapkan pembelajaran yang konvesional dengan metode ceramah, tanya jawab, pemberian tugas;

2. minat dan motivasi guru dalam inovasi yang masih rendah,

3. dalam melaksanakan pembelajaran guru jarang menggunakan media, sehingga pembelajaran cenderung membawa siswa hanya untuk membayangkan apa yang dipelajari (pembelajaran kurang nyata/riil);

4. guru sering tidak mengerjakan administrasi akademik (RPP dibuat dengan mengopi paste milik orang lain, adminisrasi penilaian dan jurnal pembelajaran belum terdokumentasi dengan baik ;

5. guru sering meninggalkan kelas saat jam mengajar dan hadir tidak tepat waktu pada jam mengajar,

6. supervisi dilaksanakan satu kali dalam satu semester dengan tujuan hanya untuk kepentingan administrasi PKG, tanpa disertai tindak lanjut.

Berdasar hasil studi dokumen yang ada di MTs Kecamatan Kajoran Tahun 2020/2021, dapat diinformasikan bahwa wilayah Kecamatan Kajoran berjarak 31 KM dari ibukota Kabupaten Magelang. Kecamatan Kajoran berbatasan dengan Gunung Sumbing di utara, Kecamatan Kaliangkrik dan Tempuran di timur, Kecamatan Salaman di selatan, Kabupaten Wonosobo dan Purworejo di barat. Luas wilayah Kecamatan Kajoran 83,41 km² dengan kepadatan penduduk $634 \mathrm{jiwa} / \mathrm{km}^{2}$ dengan ketinggian $578 \mathrm{~m}$ dari permukaan air laut. Jumlah desa dan kelurahan 29. Kecamatan Kajoran terletak di lereng Gunung Sumbing, sebagian besar daerah perkebunan, terkenal sebagai daerah sejuk di Kabupaten Magelang. Kecamatan Kajoran mempunyai tempat wisata yaitu Air terjun Curug Silawe di Desa Sutopati yang airnya bersumber dari Gunung Sumbing. Selain potensi wisata, Kecamatan Kajoran mempunyai potensi pertanian untuk dikembangkan, karena tanah yang subur serta ketersediaan air yang cukup untuk digunakan sebagai pengairan Secara geografis berada di terletak daerah pegunungan, dengan posisi geografis antara $110^{\circ} 26^{\prime} 51^{\prime \prime}$ dan $110^{0} 26^{\prime} 53^{\prime \prime}$ Bujur Timur serta 7019'13" dan 7019'15" Lintang Selatan. (https://id.wikipedia.org/wiki/Wikipedia, diakses pada 1 Juli 2020 pukul 06.00)

Terdapat 7 MTs binaan di Kecamatan Kajoran dengan jumlah rombel yang bervariasi sebagaimana terlihat pada tabel 2 berikut ini :

Tabel 2. Keadaan Jumlah Siswa dan Rombel MTs se Kecamatan Kajoran

\begin{tabular}{|c|c|c|c|c|c|c|c|c|c|c|c|c|}
\hline \multirow{2}{*}{ No } & \multirow{2}{*}{ Nama Madrasah } & \multicolumn{3}{|c|}{ Kelas VII } & \multicolumn{3}{|c|}{ Kelas VIII } & \multicolumn{3}{|c|}{ Kelas IX } & \multirow{2}{*}{$\begin{array}{l}\text { Jml } \\
\text { Tot }\end{array}$} & \multirow{2}{*}{$\begin{array}{r}\mathrm{Jml} \\
\mathrm{Rmb}\end{array}$} \\
\hline & & $\mathrm{L}$ & $\mathrm{P}$ & Jml & $\mathrm{L}$ & $\mathrm{P}$ & Jml & $\mathrm{L}$ & $\mathrm{P}$ & Jml & & \\
\hline 1 & MTs Ma'arif Wuwuharjo & 17 & 29 & 46 & 30 & 23 & 53 & 25 & 22 & 47 & 146 & 6 \\
\hline 2 & MTs Al Islam Wonogiri & 10 & 15 & 25 & 15 & 6 & 21 & 14 & 8 & 22 & 68 & 3 \\
\hline 3 & $\begin{array}{l}\text { MTs Muhammadiyah } \\
\text { Madukoro }\end{array}$ & 7 & 10 & 17 & 11 & 12 & 23 & 7 & 7 & 14 & 54 & 3 \\
\hline 4 & $\begin{array}{l}\text { MTs Salafiyah Maarif } \\
\text { Penjalinan }\end{array}$ & 1 & 1 & 2 & 12 & 5 & 17 & 13 & 5 & 18 & 37 & 3 \\
\hline 5 & MTs Al Iman Mranggen & 7 & 5 & 12 & 6 & 8 & 14 & 8 & 7 & 15 & 41 & 3 \\
\hline 6 & MTs Al Iman Sangen & 21 & 13 & 34 & 15 & 8 & 23 & 15 & 22 & 37 & 94 & 5 \\
\hline 7 & MTs Walisongo Sidowangi & 68 & 61 & 129 & 61 & 55 & 116 & 26 & 42 & 68 & 313 & 12 \\
\hline & Jumlah seluruhnya & 131 & 105 & 265 & 150 & 94 & 267 & 108 & 91 & 221 & 753 & 36 \\
\hline
\end{tabular}

Semua madrasah binaan tersebut memiliki kualifikasi akreditasi B, situasi dan kondisi madrasah secara umum masih memiliki banyak kekurangan dalam segala aspek standar pelayanan minimal. Hanya 2 madrasah yang layak dalam pemenuhan pelayanan standar minimal yakni : MTs Maarif Wuwuharjo dan MTs Walisongo. Keadaan Guru di MTs Kecamatan Kajoran dapat dilihat pada tabel 3 berikut ini : 
SECONDARY : Jurnal Inovasi Pendidikan Menengah

Vol 1. No 3. Juli 2021 P-ISSN : 2774-8022, e-ISSN : 2774-5791

Tabel 3 : Keadaan Jumlah Guru MTs Kecamatan Kajoran

\begin{tabular}{|c|l|c|c|c|c|c|c|}
\hline \multirow{2}{*}{ No } & \multicolumn{1}{|c|}{ Nama Madrasah } & \multicolumn{5}{|c|}{ Jumlah Guru } & \multirow{2}{*}{ Belum } \\
\cline { 3 - 8 } & & L & P & PNS & $\begin{array}{c}\text { Non- } \\
\text { PNS }\end{array}$ & JML & S1/DIV \\
\hline 1 & MTs Ma'arif Wuwuharjo & 4 & 6 & - & 10 & 10 & 1 \\
\hline 2 & MTs Al Islam Wonogiri & 5 & 5 & - & 10 & 10 & 3 \\
\hline 3 & $\begin{array}{l}\text { MTs Muhammadiyah } \\
\text { Madukoro }\end{array}$ & 4 & 6 & 1 & 9 & 10 & 2 \\
\hline 4 & $\begin{array}{l}\text { MTs Salafiyah Maarif } \\
\text { Penjalinan }\end{array}$ & 4 & 7 & - & 11 & 11 & 3 \\
\hline 5 & MTs Al Iman Mranggen & 4 & 4 & - & 8 & 8 & 3 \\
\hline 6 & MTs Al Iman Sangen & 8 & 6 & 1 & 13 & 14 & 4 \\
\hline 7 & MTs Walisongo Sidowangi & 8 & 11 & 1 & 18 & 19 & 2 \\
\hline & Jumlah Keseluruhan & 37 & 45 & 3 & 79 & 82 & 18 \\
\hline
\end{tabular}

Masih 18 Guru yang belum memenuhi kualifikasi S1 atau DIV dan hanya 3 orang berstatus PNS dengan berbagai keterbatasan karena secara administratif masih menginduk di MTs Negeri 2 Magelang yang berlokasi di Kacamatan Kaliangkrik.

Setelah dilaksanakan kegiatan supervisi secara terencana, maka terdapat beberapa hasil yang dapat dirangkum sebagai berikut:

Tabel 4. Rekap Hasil Kegiatan Supervisi Akademik

\begin{tabular}{|c|l|c|c|c|c|}
\hline No & \multicolumn{1}{|c|}{ Aspek yang disupervisi } & $\begin{array}{c}\text { Jml } \\
\text { pelaksana } \\
\text { awal }\end{array}$ & $\begin{array}{c}\text { Persen- } \\
\text { tase }\end{array}$ & $\begin{array}{c}\text { Jml } \\
\text { pelaksana } \\
\text { akhir }\end{array}$ & $\begin{array}{c}\text { Persen- } \\
\text { tase }\end{array}$ \\
\hline 1 & $\begin{array}{l}\text { Menyusun administrasi } \\
\text { pembelajaran lengkap }\end{array}$ & 40 & $49 \%$ & 68 & $83 \%$ \\
\hline 2 & $\begin{array}{l}\text { Administrasi pembelajaran berbasis } \\
\text { ITC }\end{array}$ & 26 & $32 \%$ & 60 & $73 \%$ \\
\hline 3 & $\begin{array}{l}\text { Proses pembelajaran berbasis } \\
\text { media }\end{array}$ & 27 & $33 \%$ & 65 & $79 \%$ \\
\hline 4 & $\begin{array}{l}\text { Melaksanakan model pembelajaran } \\
\text { CTL }\end{array}$ & 28 & $34 \%$ & 66 & $80 \%$ \\
\hline 5 & $\begin{array}{l}\text { Pembelajaran memanfaatkan } \\
\text { internet }\end{array}$ & 25 & $30 \%$ & 64 & $78 \%$ \\
\hline 6 & Pembelajaran sesuai jadwal & 50 & $61 \%$ & 76 & $93 \%$ \\
\hline 7 & Kesadaran inovasi pembelajaran & 40 & $49 \%$ & 68 & $83 \%$ \\
\hline
\end{tabular}

Sumber: Data Rekap hasil tindak lanjut supervisi Semester 1 Tahun 2020/2021 MTs se Kecamatan Kajoran

Dari ringkasan dalam tabel dapat dijelaskan bahwa melalui kegiatan supervisi akademik yang terprogram, terarah dan terdokumentasi yang disertai tindak lanjut, maka membawa hasil yang signifikan, karena adanya peningkatan pada tiap aspek yang menjadi titik kelemahan guru pada saat pelaksanan supervisi belum terprogram secara baik. Dari tabel 4 di atas dapat dijelaskan sebagai berikut: 
1. Penyusunan administrasi pembelajaran lengkap pada awalnya hanya 40 guru dari 82 guru atau $49 \%$, menjadi 68 guru dari 82 guru yang berarti naik secara signifikan menjadi $83 \%$ guru telah melengkapi administrasi pembelajaran;

2. Penyusunan administrasi pembelajaran yang memanfaatkan teknologi informasi dan komunikasi (ITC) pada awalnya hanya 26 guru dari 82 guru atau $32 \%$, naik secara signifikan menjadi 60 guru dari 82 guru berarti $73 \%$ guru telah memanfaatkan teknologi informasi dan komunikasi (ITC);

3. Proses pembelajaran yang mengimplementasikan pemanfaatan media awalnya hanya 27 guru dari 82 guru atau $33 \%$, naik menjadi 65 guru dari 82 guru yang berarti $79 \%$ guru telah memanfaatkan media pada proses pembelajaran;

4. Pemanfaatan model pembelajaran Contextual Teaching and Learning (CTL) pada awalnya hanya 28 guru dari 82 guru atau $34 \%$, naik secara signifikan menjadi 66 guru dari 82 guru berarti $80 \%$ guru telah melaksanakan model pembelajaran Contextual Teaching and Learning (CTL);

5. Pemanfaatan internet pada proses pembelajaran awalnya hanya 25 guru dari 82 guru atau $30 \%$, naik menjadi 64 guru dari 82 guru atau $78 \%$ guru telah memanfaatkan internet pada proses pembelajaran baik secara online maupun offline;

6. Ketepatan menaati jadwal pembelajaran yang awalnya hanya 50 guru dari 82 guru atau $61 \%$, naik secara signifikan menjadi 76 guru dari 82 guru atau $93 \%$ guru telah menaati waktu pembelajaran sesuai jadwal pembelajaran madrasah;

7. Kesadaran untuk melakukan inovasi pada proses pembelajaran awalnya hanya 40 guru dari 82 guru atau $49 \%$, naik secara signifikan menjadi 68 guru dari 82 guru atau $83 \%$ guru telah melaksanakan inovasi dalam proses pembelajaran.

Secara keseluruhan aspek yang menjadi titik kelemahan guru yang menjadi permasalahan di MTs Se Kecamatan Kajoran sudah memproleh solusi, mengalami peningkatan kinerja SDM guru ke arah yang lebih positif.

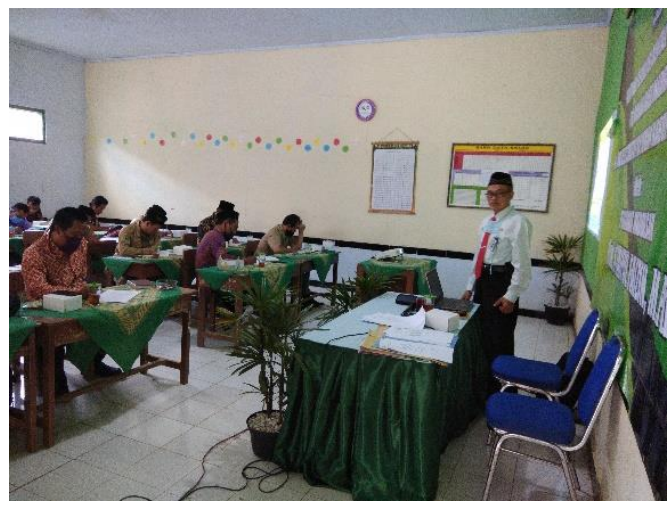

\section{Gambar 1. Penjelasan awal terhadap Guru Binaan}

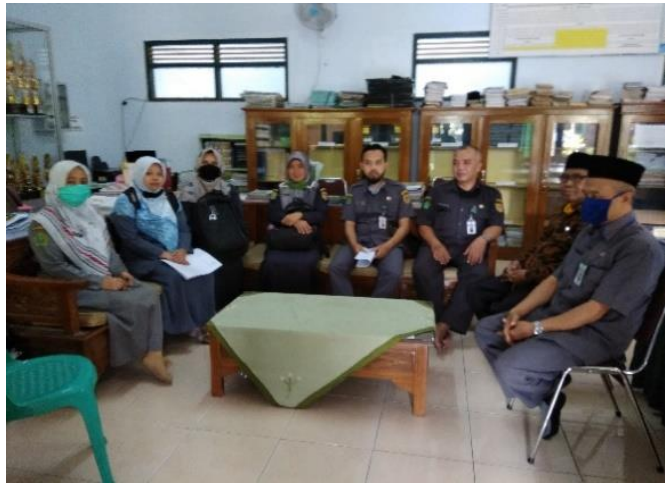

Gambar 2. Penyusunan kesepakatan bersama 


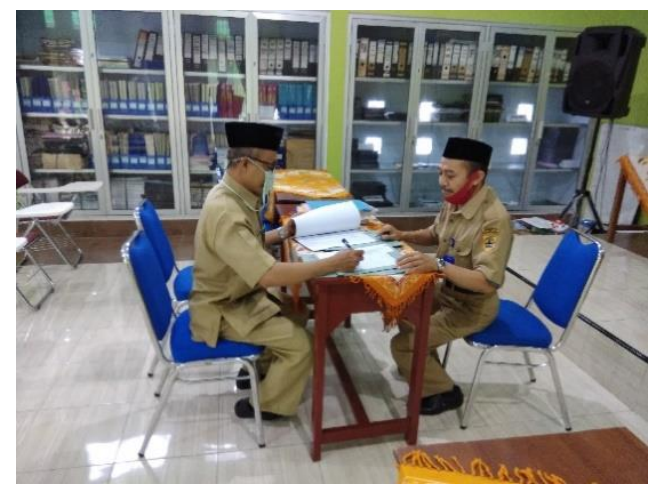

Gambar 3. Pendampingan individual

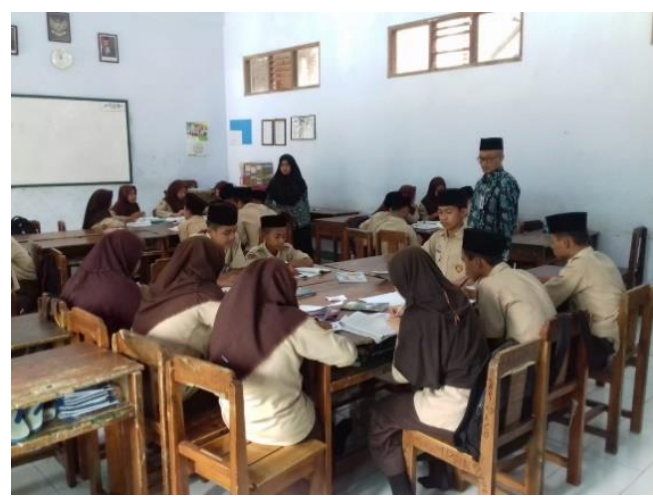

Gambar 4. Supervisi pembelajaran klasikal

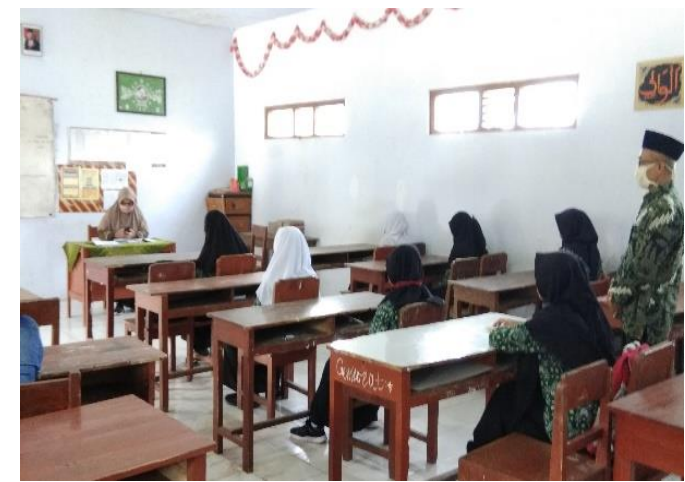

Gambar 4. Pendampingan proses pembelajaran

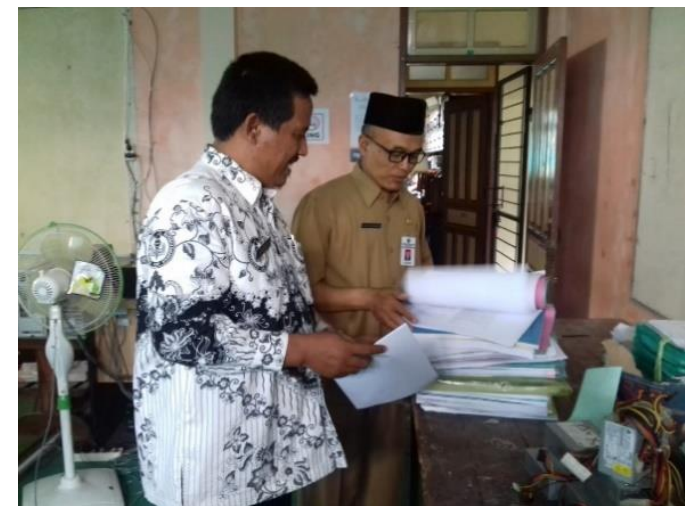

Gambar 5. Tindak lanjut pendampingan 


\section{KESIMPULAN}

Berdasarkan kegiatan supervisi sebagai best practise yang telah dilaksanakan oleh Kepala Madrasah bersama Pengawas Pembina, maka dapat disimpulkan bahwa kegiatan supervisi akademik melalui bimbingan dan latihan profesional guru dapat meningkatkan profesional guru pada aspek yang menjadi permasalahan di MTs Se Kecamatan Kajoran. Aspek-aspek kelemahan guru telah mengalami penurunan dan menunjukkan hasil ke arah yang positif atau sudah dapat teratasi. Mulai kelengkapan dokumen administrasi pembelajaran, pemanfaatan ITC, pemanfaatan media, pemanfaatan model pembelajaran CTL, pemanfaatan internet pada proses pembelajaran, kedisiplinan masuk jam mengajar, dan kesadaran berinovasi pada proses pembelajaran sudah mengalami perubahan ke arah postif (meningkat), meskipun belum mencapai kesempurnaan.

\section{DAFTAR PUSTAKA}

Bimo, Walgito, 2004. Pengantar Psikologi Umum, Andi, Jakarta. , 2010. Pengantar Psikologi Umum, Andi, Yogyakarta

Goldstein dan Gressner. (1988). Sumber Daya Manusia dan Produktivitas Kerja. Bandung: Mandar Maju.

Hamalik, Oemar. 2004. Proses Belajar Mengajar. Bumi Aksara. Jakarta.

Herawan \& Hartini. 2012. Manajemen Tenaga Pendidik dan Kependidikan dalam Manajemen Pendidikan Dosen Administrasi Pendidikan UPI. Bandung: Alfabeta.

Kamil, Mustofa. (2010). Model Pendidikan dan Pelatihan. (Konsep dan Aplikasi). Bandung: Alfabeta

Marsudi, L. 2003. Psikologi Pendidikan dan Bimbingan. Malang: UNM Press

Masaong, H.A. Kadim, 2012. Supervisi Pembelajaran dan Pengembangan Kapasitas Guru (Memberdayakan Pengawas Sebagai Gurunya Guru). Bandung: Alfabeta.

Kemendikbud. 2005. Undang-Undang Guru dan Dosen No. 14 Tahun 2005. Jakarta: Kemendikbud.

Pemendikbud, 2015. Supervisi manajerial dan Supervisi Akademik, Jakarta: PPTKBPSDMP\&PMP Kemendikbud.

Permenpan \& Reformasi Birokrasi No. 16 Tahun 2009 Tentang Jabatan Fungsional Guru dan Angka Kreditnya. Jakarta: Menteri Negara PAN \& Reformasi Birokrasi RI.

Prayitno dan Amti, Eraman. 2004. Dasar-dasar Bimbingan Konseling. Jakarta: Rineka Cipta Sagala, Syaiful. 2010. Supervisi Pembelajaran dalam Profesi Pendidikan. Bandung: Alfabeta. Sudjana . (2007). Sistem \& Manajemen Pelatihan (Teori dan Aplikasi). Bandung: Falah Production.

Suhardan, Dadang, 2010. Supervisi Profesional. Bandung: Alfabeta.

Sahertian, Piet. A. 2010. Konsep Dasar dan Teknik Supervisi Pendidikan dalam Rangka Pengembangan Sumber Daya Manusia, Jakarta: Rineka Cipta.

Surya, M.H. 2004. Bunga Rampai Guru dan Pendidikan. Jakarta: Balai Pustaka.

Wukir, 2013. Manajemen Sumber Daya Manusia dalam Organisasi Sekolah/madrasah. Yogyakarta: Multi Presindo.

. 2020 . https://id.wikipedia.org/wiki/Wikipedia, diakses pada 1 Juli 2020 pukul 06.00 